\title{
4F2 Cell-Surface Antigen Heavy Chain
}

National Cancer Institute

\section{Source}

National Cancer Institute. 4F2 Cell-Surface Antigen Heavy Chain. NCI Thesaurus. Code C124117.

4F2 cell-surface antigen heavy chain ( $630 \mathrm{aa}, \sim 68 \mathrm{kDa}$ ) is encoded by the human SLC3A2 gene. This protein plays a role in the positive regulation of amino acid transport. 